\title{
THE OLD SLAVONIC EUTHALIANA: STRUCTURE AND LANGUAGE OF THE CHAPTER-LIST TO THE FIRST EPISTLE TO CORINTHIANS
}

\author{
Mariya O. Novak \\ Kazan Federal University, Kazan, Russia
}

\begin{abstract}
The paper focuses on the composition, syntactic and lexical parameters of the Old Slavonic translation of the Euthaliana chapter-list to the first Epistle to Corinthians, previously unexplored. The chapter-list composition does not coincide with the original in all Slavic sources representing different versions of the text since it represents omitting, combining, rearranging of titles. Various translation versions reveal some differences in comparison to the Greek text structure, as well as several trends indicating the implementation of the same translation strategies as in the basic Epistle text. The $14^{\text {th }}$-century Chudov New Testament is characterized by loan translation of syntactic structures and lexical units; the $14^{\text {th }}$-century Tolstovsky Apostolus of the Preslav translation presents syntactic and lexical supplements independent from the Greek text. The 12 ${ }^{\text {th }}$-century Apostolus Christinopolitanus, synthesizing the Cyril-and-Methodius and the Preslav translations, represents moderate transformations of the Greek original, and so does the Athonite copy of the $16^{\text {th }}$ century. The author finds out that various factors determine semantic deviations from the original: conjectures, the influence of context and intertext, incorrect interpretation of the Greek source or errors in the latter; less often lapsus calami occur. The author also investigates the links between the chapter-list and the basic text of the Epistle and demonstrates that the syntactic and lexical transformations of the Slavic versions often weaken these relations.

Key words: Euthaliana, Old Slavonic Apostolus, chapter-lists, composition, syntax, lexis.

Citation. Novak M.O. The Old Slavonic Euthaliana: Structure and Language of the Chapter-List to The First Epistle to Corinthians. Vestnik Volgogradskogo gosudarstvennogo universiteta. Seriya 2, Yazykoznanie [Science Journal of Volgograd State University. Linguistics], 2018, vol. 17, no. 4, pp. 6-15. (in Russian). DOI: https://doi.org/ $10.15688 /$ jvolsu2.2018.4.1
\end{abstract}

\section{ДРЕВНЕСЛАВЯНСКАЯ ЕВФАЛИАНА: СТРУКТУРА И ЯЗЫК ОГЛАВЛЕНИЯ К ПЕРВОМУ ПОСЛАНИЮ АПОСТОЛА ПАВЛА К КОРИНФЯНАМ}

\section{Мария Олеговна Новак}

\author{
Казанский федеральный университет, г. Казань, Россия
}

\footnotetext{
Аннотация. В статье на фоне греческого источника анализируются композиция, синтаксические и лексические параметры древнеславянских переводов одного из ранее не исследованных сопроводительных текстов к Посланиям апостолов - оглавления к первому посланию коринфянам. В различных версиях перевода выявлен ряд несоответствий структуре греческого текста оглавления, а также несколько тенденций, указывающих на реализацию тех же переводческих стратегий, что и в переводах основного текста Апостола: для
} 
Чудовского Нового Завета XIV в. характерно калькирование синтаксических структур и лексических единиц, образованных путем сложения основ; для Толстовского Апостола XIV в. - образца преславского перевода синтаксическое и лексическое дополнение исходного текста. Христинопольский Апостол ХІІ в., синтезирующий кирилло-мефодиевский и преславский переводы, и список афонской редакции XVI в. представляют умеренные преобразования греческого оригинала. Выяснено, что лексико-семантические отклонения от оригинала определяются различными факторами: конъектурой, влиянием контекста и интертекста, неточным пониманием греческого источника либо искажениями в нем, реже - lapsus calami. Установлено, что синтаксические и лексические трансформации славянских версий оглавления нередко ослабляют его связь с основным текстом послания.

Ключевые слова: Евфалиана, древнеславянский Апостол, оглавления, композиция, синтаксис, лексика.

Цитирование. Новак М. О. Древнеславянская Евфалиана: структура и язык оглавления к первому посланию апостола Павла к коринфянам // Вестник Волгоградского государственного университета. Серия 2, Языкознание. - 2018. - Т. 17, № 4. - C. 6-15. - DOI: https://doi.org/10.15688/jvolsu2.2018.4.1

\section{Вводные замечания}

Данная статья представляет фрагмент исследования, посвященного сопроводительным текстам к Деяниям и Посланиям апостолов в древнеславянском переводе - так называемому аппарату Евфалия, по имени автора IV-VI вв. н. э., которому христианская традиция наиболее часто приписывает создание этих текстов - оглавлений, предисловий, списков библейских цитат и т. д. [Евфалий, 2013]. К настоящему моменту греческая традиция Евфалианы детально проанализирована в англоязычной научной литературе [Blomkvist, 2012; Willard, 2009], но славянский перевод пока малоизучен (отдельные наблюдения над лексикой и синтаксисом Евфалианы см. в [Новак, 2017a, 2017б], текстологическое описание предисловия к посланиям ап. Павла и его издание по ряду источников см. в [Tak, 2003]). Оглавления не становились еще предметом специального исследования.

Ниже будет обсуждаться репрезентация оглавления первого послания ап. Павла коринфянам в разновременных версиях древнеславянского перевода Апостола на фоне греческого первоисточника (Migne, p. 753, 756). Выбор объекта исследования продиктован политематичностью названного послания, определяющей разнообразие языковых единиц в составе оглавления. Каждое заглавие отсылает читателя к той или иной крупной теме послания, посвященного различным настроениям в коринфской общине, вопросам эсхатологии, брака, отношения к идоложертвенной пище, практикам ранней церкви и т. д. [Гатри, 1996, c. 354-356].

\section{Источники и методы исследования}

Выбор источников соотносится с общей текстологической схемой истории текста Апостола: толковый Христинопольский Апостол XII в. (Львовский ист. музей, ОР, № 37, далее - Христ) отражает первоначальный перевод с присутствием преславских элементов, к которому затем возвращается афонская редакция (ее представляет последовательный (четий) список XVI в. ТСЛ71, РГБ, ф. 304.I). Самостоятельный преславский перевод содержит последовательный Толстовский список XIV в. (РНБ, Q.п.I.5, далее - Толст). В Чудовском Новом Завете XIV в. (опубликован в 1892 г., далее - Чуд) также присутствуют предисловия к посланиям, отражающие вполне своеобразные лексические и синтаксические решения. Все рукописи, кроме Чуд, изучались по копиям ${ }^{1}$, Толст - также de visu. Перевод отдельных новозаветных чтений на русский язык дается по (Цитата из Библии).

Сначала мы охарактеризуем вариации структуры оглавления в разных славянских версиях, затем обратимся к сравнительному семасиологическому анализу переводческих стратегий на уровнях синтаксиса и лексики, а также к сопоставлению оглавления с основным текстом послания. Инвариантом и основанием для сравнения послужил греческий текст оглавления, для интерпретации которого использовался (Alpha).

\section{Композиция оглавления}

Оглавление открывается своего рода заголовком, который находится вне общей нумерации в Христ и Толст, а в Чуд включен в 
нее: $\widetilde{a} O$ иножанши $(X)$ и разлнчны $(X)$ ЕПнСТОАНГа НСПРАВАЕ(Нь)Ю НМОГЧН КОРНне,АН'

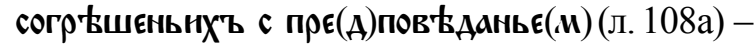

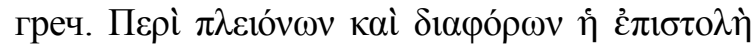

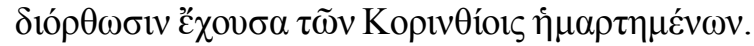
При этом лексические единицы, соответствующие предложно-падежной форме с пре(А)пов ВАанье(.м), в оригинале и других славянских источниках открывают следующую

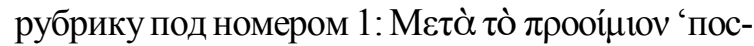
Ле вступления' - по прєА'ЪП(и)санню (Христ, Л. 136 об., ТСЛ71 Л. 56), По ПрЕАЪГААНнн (Толст, л. 10г).

Версии древнеславянского перевода поразному отражают порядок расположения и содержание рубрик оглавления, которые могут объединяться либо опускаться. Нумерация заглавий в славянских источниках не совпадает. Например, в Толст заглавие да не осужають огчнтєАь (Л. 10г) обособлено (как и в греческом тексте) и имеет номер -.्र. (3), тогда как в Христ (л. 136 об.) и Чуд (л. 108a) оно объединено с другими в более крупные рубрики, под номерами · $\cdot \widetilde{\mathbf{a}} \cdot(1)$ и $\cdot \widetilde{\mathbf{B}} \cdot(2)$ соот-

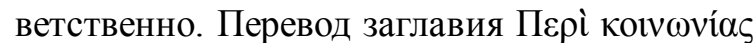
$\theta \varepsilon о \pi \rho \varepsilon \pi о \tilde{v} \varsigma$, оひ $\pi \lambda \eta \sigma \mu о v i \kappa \tilde{\eta} \varsigma$ «О боголепном причащении, не до пресыщения» (здесь и далее перевод с греческого наш. $-M$. H.) помещен в Tолст, в отличие от оригинала и других славянских источников, не сразу после заглавия «О внешнем виде христиан», но через одну позицию. Перевод заглавий «О бра-

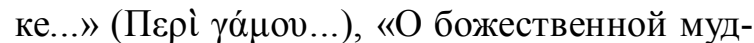

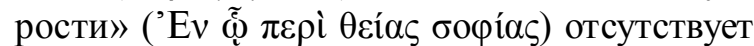

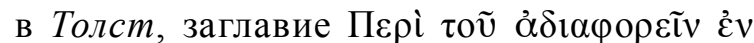

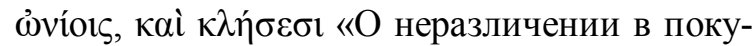
паемых и приглашениях» не отражено в Христ и ТСЛ71.

Среди списков XII-XIV вв. наибольшее количество перечисленных заглавий насчитывается в Толст - 22, в Христ их всего 9, в Чуд16. Столь существенное расхождение объясняется данными списка XVI в. TCЛ71, где чернилом пронумерованы 9 более крупных рубрик и киноварью - еще 15, входящих в состав «черных глав» (л. 56-56 об.). Прообраз этой упорядоченной и детализированной нумерации дает $X p u c m$, где также присутствуют 9 крупных рубрик с более мелким членением внутри, однако 15 подчиненных глав там не нумеруются - они лишь отмечены малыми киноварными инициа- лами. В Толст и Чуд данная иерархия не выражена: рубрики пронумерованы подряд, при этом нумерация не имеет отношения к структуре апракоса, но значима для келейного чтения.

\section{Синтаксические трансформации текста}

1. Чуд использует строгие синтаксические кальки, что хорошо соотносится с переводческой стратегией Чудовской редакции в основном тексте Апостола. В других славянских версиях отражено более свободное обращение с оригиналом.

В оригинале оглавления частотны конструкции с субстантивированным инфинитивом. В Чуд он регулярно переводится инфинитивом же, предшествуемым относительным местоимением єжє - славянским функциональным коррелятом греческого артикля. Толст предпочитает финитные формы глагола, Xpuсm может использовать именную форму либо (что происходит чаще) сохранять инфинитив, расширяя при этом синтаксическую конструкцию, вводя безличную форму презенса. Примеры помещены в таблицу, приведенную ниже.

Обращает на себя внимание препозиция

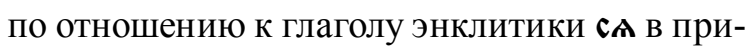
веденных контекстах Толст, отражающая живой раннедревнерусский узус (см. [Зализняк, 2004 , c. 188]).

2. Греческий порядок слов воспроизводится именно в Чуд. Его сохранение может приводить (в силу стремления ранневизантийского оригинала к инверсии) к разрушению связности славянского контекста: $\mathrm{O}$ мнножаншн( $\mathrm{X}$ )

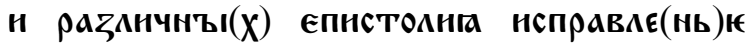

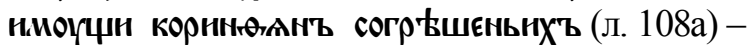

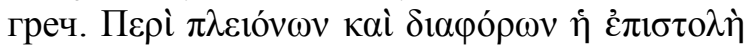

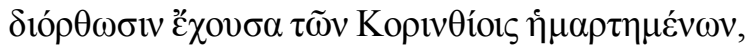
буквально «О множественных и различных послание исправление имеющее коринфянам согрешениях». Если развернуть данную инверсию, можно предложить следующий перевод на русский язык: «Послание коринфянам, имеющее исправление о множественных и различных согрешениях».

В Христ контекст гармонизирован бла-

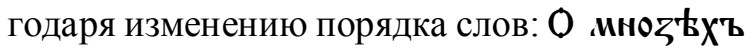

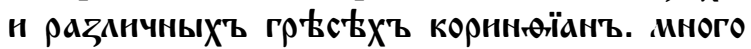
нсправакнні нмать єпнстолна (л. 136 об.; 
Способы передачи греческого субстантив ированного инфинитива

\begin{tabular}{|c|c|c|c|c|}
\hline $\begin{array}{c}\text { Греческий } \\
\text { текст }\end{array}$ & Xpucm & Толст & पyd & ТСЛ 71 \\
\hline 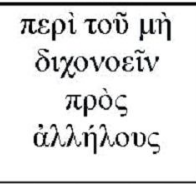 & 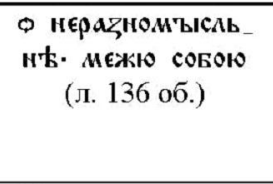 & 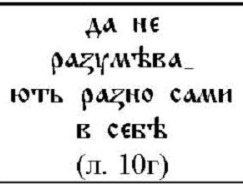 & 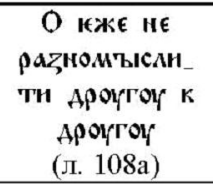 & 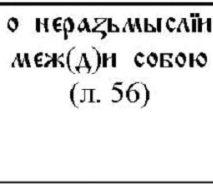 \\
\hline 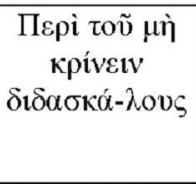 & 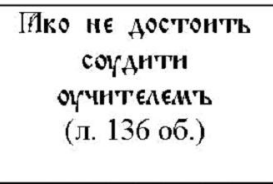 & $\begin{array}{c}\text { Aа не } \\
\text { कсужа10Tb } \\
\text { оучHTEAb } \\
\text { (ग. 10г) }\end{array}$ & 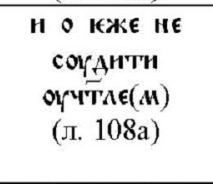 & 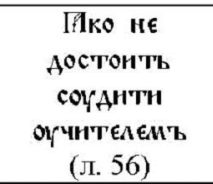 \\
\hline 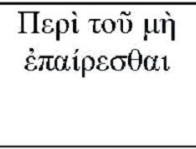 & 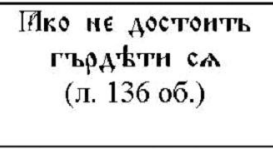 & $\begin{array}{l}\text { AА CA HE } \\
\text { B'bZHOCATb } \\
\text { (J. 10Г) }\end{array}$ & 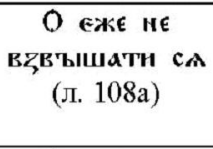 & 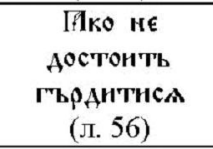 \\
\hline 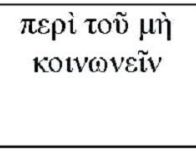 & 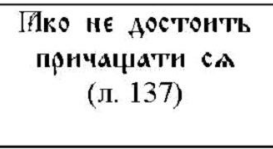 & $\begin{array}{c}\text { Ad cA HE } \\
\text { прнчацанT' } \\
\text { (л. 11a) }\end{array}$ & $\begin{array}{c}\text { O ЕЖЕ HЕ } \\
\text { ПрНОБцАТН СА } \\
\text { (Л. 1086) }\end{array}$ & 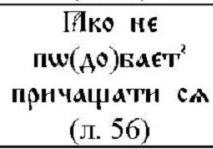 \\
\hline 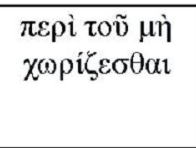 & 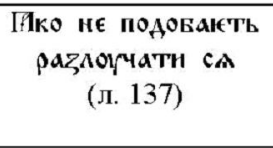 & 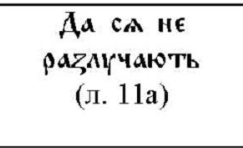 & 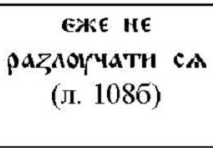 & 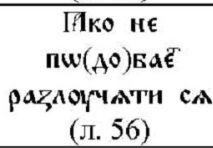 \\
\hline 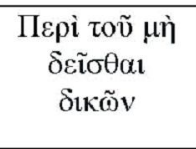 & 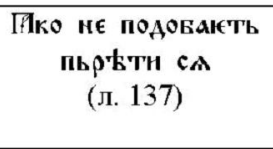 & $\begin{array}{c}\text { Aа не нчют'т } \\
\text { сҮАА } \\
\text { (Л. 10г) }\end{array}$ & $\begin{array}{l}\text { О КЖЕ НЕ } \\
\text { ПОАОБАКТЬ } \\
\text { ПрТТИ СА } \\
\text { (Л. } 108 \mathrm{a} \text { ) }\end{array}$ & $\begin{array}{c}\text { Пко нє } \\
\text { пшАоваєТь } \\
\text { пр'ТтнсА } \\
\text { (л. 56) }\end{array}$ \\
\hline
\end{tabular}

также в ТСЛ71, л. 56). Предложение становится двусоставным благодаря переводу причастия है $\chi 0 v \sigma \alpha$ финитной формой глагола н.мтти в функции сказуемого, которая вместе с подлежащим єпнстолна замыкает фразу. Форма грtck又 ъ становится центром синтагмы. Вместе с тем уход от сверхсложной инверсии оригинала не означает ее полной отмены в Xрист, поскольку второстепенные члены предложения находятся в препозиции относительно предикативного центра.

Толст еще дальше уходит от оригинала, существенно трансформируя текст: зачатци

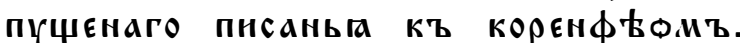

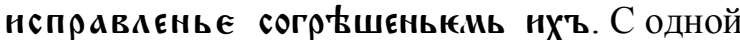
стороны, опущены эпитеты и причастная форма, в результате чего появляются два номинативных предложения, с другой - введена форма зачатци. Последняя не имеет коррелята в оригинальном тексте, однако входит в состав типового заголовка зачатци кннг'ъ, предваряющего в Толст оглавление каждого апостольского послания, ср. заголовки на листах 19a (2Кор.), 24в (Гал.), $30 б$ (Флп.), 32а (Кол.), 346 (1Фесс.), 37а (1Тим.), 40в (2Тим.), 42a (Тит.), 43а (Фил.), 43в (Евр.), 53б (1Петр.), а также их лексические варианты, содержащие zачамо (л. 2в, Рим.), начатци (л. 27в, Еф., л. $36 \mathrm{a} 2 Ф е с c$.$) .$

Приверженность Чуд к воспроизведению греческого инверсированного порядка слов обнаруживается и в следующем переводе:

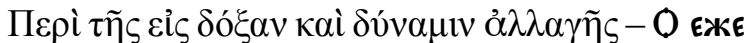

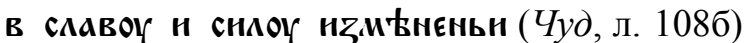

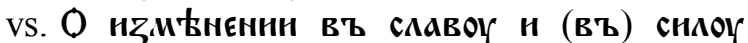
(Христ, Л. 137; ТСЛ71, Л. 56 об.), О пре.МЊненнн гакО БУ(АЕТЬ ВЪ СААВУ и ВЪ снАу (Толст, л. 11a). Христ и Толст, в отличие от Чуд, не используют славянский «артикль» и трансформируют исходный порядок слов. Толст при этом вводит не имеющую греческого коррелята глагольную форму вг (Аєть в сопровождении союза гако, формируя таким образом придаточное предложение и уточняя временную перспективу высказывания.

3. Объединение названий глав в более крупные рубрики может приводить к несовпадению синтагматического членения в греческом и славянском текстах. Например, греческий первоисточник представляет два разных заглавия: 


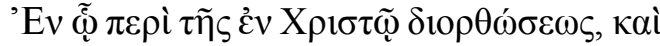

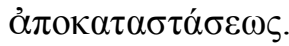

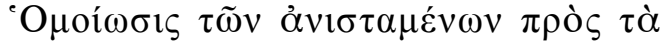

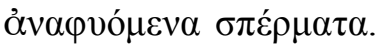

Их структуру в общих чертах наследуют Христ и Толст, соответственно:

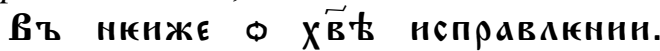
н оустрокнїн.

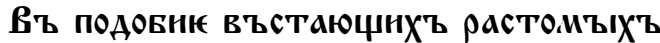
сҺ.менъ (л. 137; ТСЛ71 = Христ, за исключением растогчн $(X)$, л. 56 об.);

К. О нсправленин $О X^{\text {Tे }}$ О ОүстТавл(E)нн(н)

ка̃. Прнтъча - въскрБшемы(X). гако к то.мГ Подовьно єсть (л. 11a).

Чуд, что нетипично, отклоняется от греческого, объединяя рубрики и отражая новую синтаксическую связь как результат появления наречной формы: В нєнже О ІЖЖЕ

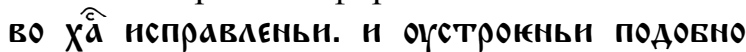
встающн(м) взрастающнХ' сЪ.МЕнъ (л. 108б).

Вместе с тем, несмотря на формальное сходство с рубрикацией в греческом, Христ и Толст демонстрируют вполне оригинальные синтаксические решения, довольно далеко уводящие славянский текст от первоисточника. При этом первое из двух приведенных заглавий представляет лишь одну заметную вариацию, связанную с наличием / отсутствием славянского артикля нжє и порядком слов: $\pi \varepsilon \rho і$

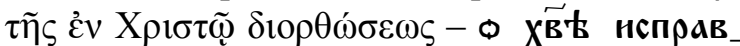

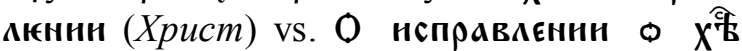

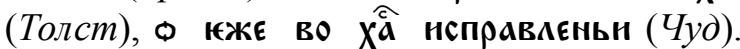
Здесь калькирующим источником предсказуемо оказывается Чуд, тогда как Xрист использует форму притяжательного прилагательного $\mathbf{X} \mathbf{B} \mathbf{k}$, а Tолст предлагает метатезу синтаксических элементов.

Второе греческое заглавие, менее прозрачное по структуре, демонстрирует больше преобразований исходного текста в славянских версиях. Греческую фразу 'О

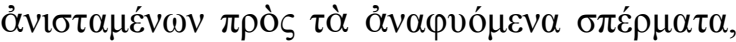
отсылающую читателя к 15-й главе послания, можно перевести на русский язык так: «Сходство (подобие) воскрешаемых (воскресающих) с прорастающими семенами». Соседство двух причастных форм, в генитиве и аккузативе, представляет, по-видимому, некото- рую трудность для славянских интерпретаторов. Так, в Христ и ТСЛ71 оба причастия стоят в генитиве, что затемняет синтаксические связи; номинативная форма 'O 'подобие' передается аккузативом с предлогом, что свидетельствует о стремлении связать заглавие с предыдущим, несмотря на отсутствие такой связи в оригинале.

Решение Толст указывает на то, что содержание контекста прекрасно понято, но передано менее сжато, нежели в греческом: се-

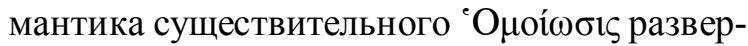
нута в целое придаточное предложение гако к тому подовьно єсть; в главное предложение введено опорное слово прнтъъча, не имеющее параллели в греческом. Последнее позволяет инверсировать компоненты исходно-

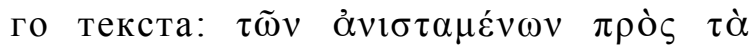

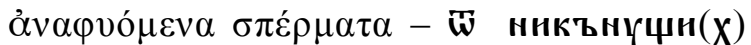
съ.менъ О въскрҺшємы(X). Что касается причастных форм, их «проблема» решена в версии Толст путем изменения падежных параметров. Залоговые характеристики причастий также переданы в Толст точнее, чем в Христ, где медиальность формы ờ $\alpha \varphi v o ́ \mu \varepsilon v \alpha$

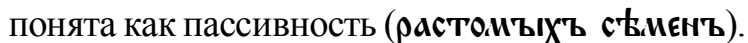

4. Для Толст в целом характерно расширение отдельных заглавий.

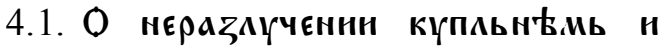

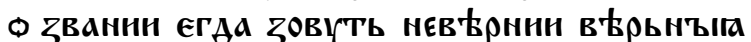
(Толст, Л. 11a) vs. О ЕЖЕ нЕ раZно БЪтTH СОвокогПАєнЫМъ и званЫМъ (Чуд, Л. 108б; в Христ и ТСЛ71 заглавие отсутствует) - греч.

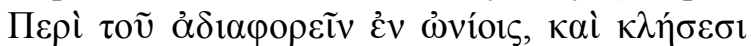
«О неразличении в покупаемых и приглашениях». Данное заглавие отсылает к 1Кор.10:27, где ап. Павел разрешает верующим принимать приглашения нехристиан разделить с ними трапезу и есть любую купленную теми пищу. В Толст, в целях разьяснения слишком лаконичного контекста, вводится дополнительное придаточное предложение, не имеющее соответствия в греческом. Кроме того, пересмотрены отношения между однородными членами: если в оригинале таковыми являются две формы датива, не относящиеся к теме данного заглавия, то в славянском тексте вторая из

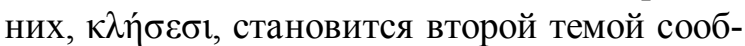
щения (О неразмгчєнни и О 弓Ванни). Первая форма датива, غ̉v ف̉víors, преобразуется в согласованное определение, что также доволь- 
но своеобразно: в традиции славянской переводной книжности адъективы передавали обычно формы родительного приименного (обзор мнений по этому вопросу см. в [Чевела, 2010, с. 178]).

На этом фоне совершенно иначе выглядит Чуд, где снова реализуется переводческая установка на калькирование греческого синтаксиса: субстантивированный инфинитив переведен инфинитивом же, датив - дативом. При этом обращает на себя внимание отсутствие предлога при именах в дательном падеже

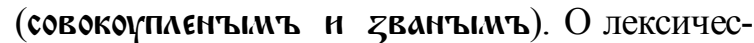
кой параллели ف̈víors - совокоупмєнъымъ будет сказано ниже, в разделе, посвященном лексике.

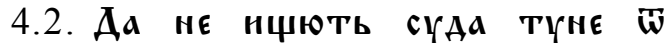

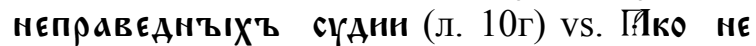

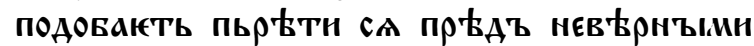
(Христ, Л. 137; ТСЛ71, Л. 56), О КЖе не

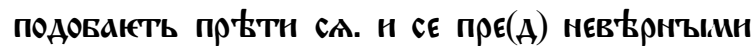

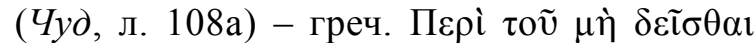

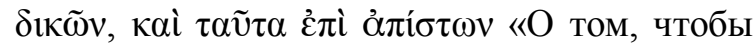
не нуждаться в судах, и притом у неверующих». Расширение контекста в Толст связано, во-первых, с введением не обусловленной оригиналом формы сганн, что приводит к эмфатическому удвоению: скаd - сганн; появление наречия тү(не 'напрасно' также не поддержано оригиналом. Возможно, это результат переосмысления первоначального ту, которое могло передавать греческое указательное местоимение $\tau \alpha \tilde{\tau} \tau \alpha$.

4.3. О скц(жащнхъ въ црк̈вахъ (л. 10г) vs. Ф смоугахъъ (Христ, л. 136 об., ТСЛ71, л. 56), ○ пнтогргигах'ъ же (Чуд, Л. 108а) - греч. Пєрі̀ $\lambda \varepsilon ı \tau о v \rho \gamma і \tilde{\omega} v$ «О служениях». Греческий первоисточник, отсылая к 3-й главе послания, где говорится о служении первохристианских наставников (Павла и Аполлоса), вместе с тем не предлагает такой конкретизации, какая наблюдается в Толст.

4.4. О овра弓' рн弓Ъ муЖЕскъ (Л. 11а)

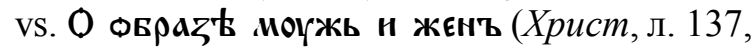
Чуд, л. 108б, ТСЛ71, л. 56 об.) - греч. Пврі̀

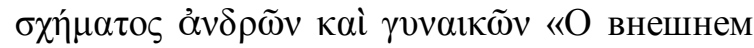
виде мужчин и женщин». Толст снова дополняет контекст, однако искажает содержание заглавия, отсылающего к одиннадцатой главе послания. Речь там идет не столько об одежде, сколько о прическах и головных уборах христиан - и мужчин, и женщин.

\section{Лексико-семантические трансформации}

1. Оглавление отражает лексические решения, характеризующие типичные переводческие стратегии той или иной редакции основного текста Апостола.

1.1. Заимствования:

въсовъ чїстї (Христ, Л. 137), ку.мнирьскъ

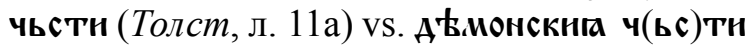
(Чуд, л. 108б, ТСЛ71, л. 56 об.) - греч.

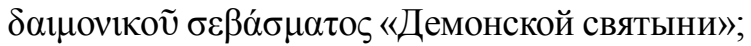

ф слоггахъ (Христ, л. 136 об., ТСЛ71, л. 56), О смцжацнХъ въ црб̈ваХ'ъ (Толст, л. 10г) vs. Ф Антогргигахъ же (Чуд, л. 108а) греч. Пврі $\lambda \varepsilon ı \tau о \cup \rho \gamma \imath \tilde{\omega} \nu$ «О служениях»;

Арог弓ни (Христ, л. 137; ТСЛ71 Арогsн, Л. 56), котор' $\mathbf{W}$ нен (Толст, Л. 11a) vs. ЕТерн

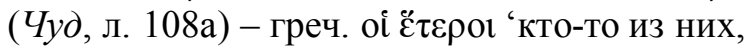
тот или другой'.

Как видим, Чудовская версия предпочитает заимствованные основы.

1.2. Кальки:

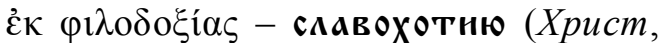
л. 136 об.), о смавохотїн (ТСЛ71, л. 56),

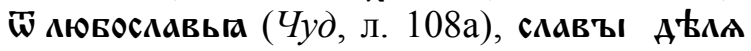
(Толст, л. 10г);

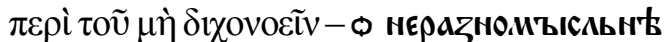
(Христ, л. 136 об.), Ф неразь.мыскїн (ТСЛ71, Л. 56), О КЖе не разномЫсАнтн (ЧУд, Л. 108а), да не разу.йвають разно (Толст, Л. 10Г);

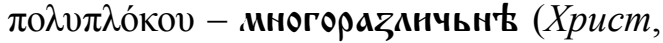
Л. 137, ТСЛ71, Л. 56 Об.), МнОГОПАЕТТНВ(М) (Чуд, л. 108б), стропотньн (Толст, л. 11а); $\theta \varepsilon$ олрвлог̃ Чуд, л. 108б, ТСЛ71, л. 56 об.), А фппоть Бйн (Толст, л. 11a).

Все источники, кроме Толст, предлагают кальки двухосновных греческих образований, и в Чуд они наиболее строги с точки зрения структуры: ср. расположение лексических основ в образовании (Аюгославью), и семантики: ср. корреляцию $\pi о \lambda v \pi \lambda o_{\kappa} о v$, где

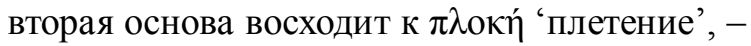
МнОГОПАЕTЕН'(.М).

Толст, напротив, предпочитает в таких случаях словосочетания, что вполне согласуется с тем, как переводятся словосложения в данной версии основного текста Апостола (подробнее см. в [Новак, 2014, с. 16-43]).

2. В Толст обнаружены регионализмы, отсутствующие в других источниках: моравиз- 
мы ко.мканнє 'причащение, евхаристия' и махъжена 'супруГи', усвоенные южно- и восточнославянской книжностью [Максимович, 2008 , с. 110,112$]$. Интересно, что существительное махъжєна употреблено в плюральной форме, тогда как связанное с ним местоимение - в двойственном числе: Да са не

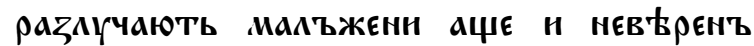
Есть КОТОрЫ $\mathbf{W}$ нею (Л. 11а). ПО-ВИДИМОМУ, здесь представлено дистрибутивное двойственное: речь идет о многих семьях, но отношение к вере может быть различным внутри одной супружеской пары. Этот нюанс способствует успешному решению проблемы пере-

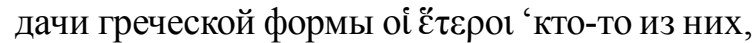
тот или другой'.

В оригинале и других версиях перевода упоминаются мужья и жены: не раZмогчатн сА МОГЖЕ.ИЪ $\mathbf{W}$ Женъ (Христ, Л. 137; ЧУд, Л. 108а;

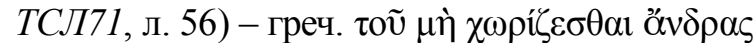

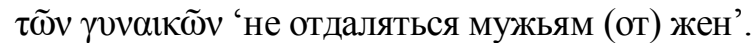

3. Отклонения от семантики оригинала отмечены во всех версиях, кроме выверенной поздней, отраженной в списке ТСЛ71 XVI века.

3.1. О чнСТОТ' Н НЕАЪВОЖЕНЬСТВН (Христ, Л. 137) vs. О чТООТ' н АВОЖеньств' (Чуд, л. 108a), О чнстоть плотьнь н О вторьн ЖеннтвЊ (Толст, Л. 11a), О чнс тот', н Ф Авоу врака $(\mathrm{X})$ (ТСЛ71, Л. 56) -

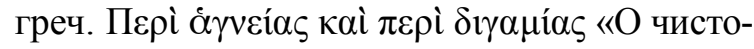
те и о второбрачии». Данное заглавие отсылает к седьмой главе послания, где речь идет о том, что любому человеку - и безбрачному, и вдовому - лучше оставаться в целомудрии; но тем, кому трудно воздерживаться, апостол рекомендует вступать в брак (в том числе и вдовам - в повторный): «Безбрачным же и вдовам говорю: хорошо им оставаться, как я. Но если не [могут] воздержаться, пусть вступают в брак; ибо лучше вступить в брак, нежели разжигаться» (1Кор.7:8-9, в синодальном переводе) (Цитата из Библии). «Лишнее» отрицание могло появиться случайно, однако нельзя исключить, что в Христ отражена своего рода аскетическая рационализация, согласно которой второй брак по определению хуже безбрачного состояния. Эта идея, возможно, усиливается и соседством слова чнстота, с КОТОРЫМ НЕАЪВОЖЕнЬСТВО СООТНОСИТСЯ ЛУЧше, чем Аъвожєньство. Остальные версии текста, однако, следуют смыслу греческого первоисточника.

3.2. прнчацати са всьхъ (Христ, л. 137) vs. вњсомъ (Толст, л. 11a, Чуд, л. 108б),

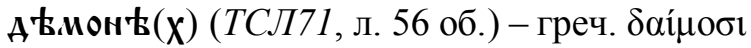
'демонам'. Дефект в Христ, очевидно, связан с качеством письма в антиграфе / протографе.

3.3. О вЪСК $($ (СЕ)НЬН ТЕАЕСЪ ПРАВЕАНЫ(X)

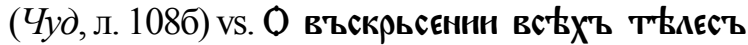
(Христ, Л. 137, ТСЛ71, Л. 56 об.), О въскрНшеннн телесьн'й (Толст, л. 11a) - греч. Пєрі

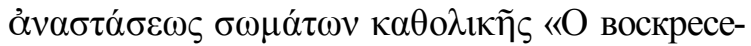
нии тел всеобщем». Христ и ТСЛ71 точнее всего передают семантику оригинала; Tолст опускает определение вовсе, а Чуд, напротив, вводит некую интерпретацию, предполагающую воскресение не всех, но лишь праведников.

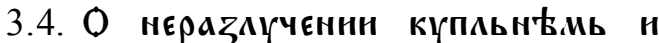
Ф ҚВанни (Толст, Л. 11a) vs. $О$ ЕЖе не разно

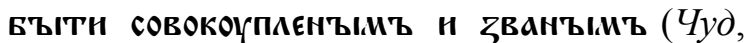
л. 108б; в Христ и ТС Л71 заглавие отсутству-

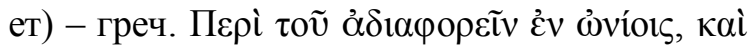

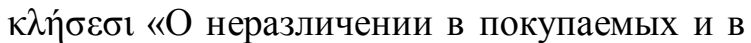
приглашениях». Это заглавие обсуждалось выше в связи с синтаксическими решениями; здесь укажем на неточное прочтение в Чуд

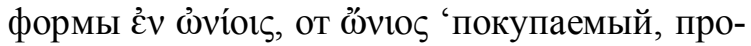
даваемый'. Возможно, такой выбор спровоцирован соседством с формой званымъ: «совокупление» (собрание) предстает как результат приглашения, хотя в действительности заглавие отсылает к рекомендации не заострять внимания на происхождении предлагаемой гостям пищи (связана ли она с языческими жертвоприношениями или нет): «Если кто из неверных позовет вас, и вы захотите пойти, то все, предлагаемое вам, ешьте без всякого исследования, для [спокойствия] совести» (1Кор.10:27, синодальный перевод) (Цитата из Библии).

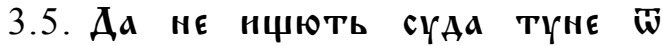
неПРАВЕАНЫХ' СКАНн (Л. 10Г) VS. ПЯКО не ПОАОБАКТЬ ПЬРЬТН СА ПрЬАЪ НЕВЬРНЫМн (Христ, Л. 137; ТСЛ71, Л. 56), О КЖе не ПОАОБАЮТЬ ПрБТН СА. Н СЕ ПрЕ(А) неВЪРНЫЫИН

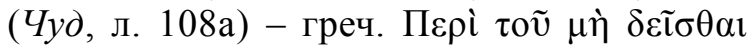

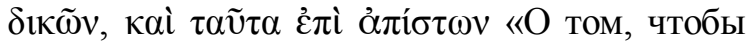
не нуждаться в судах, и притом у неверующих». Словоупотребление Толст $\mathbf{\boldsymbol { \theta }}$ мєпра_ вєАныХ'ъ отражает неверное понимание греческого соответствия غ̇лі ỏ 
'неверующий'). С осторожностью можно предположить, что это решение появилось не случайно, но под влиянием формы сүАнн (также введенной в текст независимо от оригинала): сочетание сү(дни нєправєднЫн МоГЛо восприниматься коллективной памятью славянских книжников (о ней см. [Гардзанити, 2014]) как устойчивое благодаря евангельской притче о неправедном судье (Лк.18:1-7). Ср., например, это словосочетание в Остромировом Евангелии (л. 114в) (ЕвОстр, с. 114) и Архангельском Евангелии (л. 69) (ЕвАрх, с. 179).

3.6. О напастн (Толст, л. 11a) vs. О прЊХОЖенни (Христ, Л. 137, Чуд, Л. 108б), ○ прнхож(А)єнїн (ТСЛ71, л. 56 об.) - греч. $\pi \varepsilon \rho \grave{~} \sigma \nu \mu \pi \varepsilon \rho \iota ф о \rho \tilde{\alpha} \varsigma$ «Об общении (о связях)». Заглавие отсылает к 9-й главе послания, где говорится о широком круге общения апостола: «...для иудеев я был как иудей, чтобы приобрести иудеев; для подзаконных был как подзаконный, чтобы приобрести подзаконных; для чуждых закона - как чуждый закона, не будучи чужд закона пред Богом, но подзаконен Христу, - чтобы приобрести чуждых закона; для немощных был как немощный, чтобы приобрести немощных. Для всех я сделался всем, чтобы спасти по крайней мере некоторых» (1Кор.9:20-22). Очевидно, в Толст отражено неразличение образований

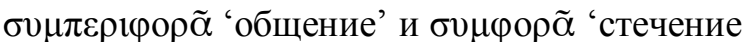
обстоятельств, происшествие, в том числе несчастье, беда'. Последнее нередко переводится в древнеславянской книжности именно как напасть (Slovník, II, s. 300). Смешение лексических единиц могло либо произойти в восприятии славянского книжника, либо появиться в самом греческом источнике.

\section{Выводы}

Древнеславянские версии оглавления к первому посланию коринфянам были проанализированы с позиций их соответствия композиции греческого текста, его синтаксической структуре и лексикону, а также основному тексту послания.

Выявлено, что композиция оглавления не совпадает с оригиналом во всех славянских источниках, представляющих разные версии текста, - пропуск, объединение, перестановка заглавий. Нумерация упорядочена в позднем списке
$T C Л 71$, где обнаружена дифференциация более крупных (9) и подчиненных (15) рубрик. В Толст и Чуд иерархия заглавий отсутствует.

На синтаксическом уровне отмечены две наиболее значительные тенденции: синтаксическое калькирование в Чуд (в частности, воспроизведение субстантивированных инфинитивов и порядка слов) и независимость Tолст от греческих синтаксических структур. В последнем источнике в целом ряде случаев наблюдается синтаксическое расширение, не поддерживаемое оригиналом. Списки Христ и TCЛ71 представляют менее заметные несовпадения с греческим.

На лексическом уровне отмечена тенденция к реализации тех же переводческих стратегий и техник, что и в основном тексте Апостола: Чуд предпочитает заимствования и кальки, Толст - свободную интерпретацию. Вместе с тем, все источники представляют различного рода лексические отступления от оригинала. Они могут быть результатом конъектуры, влияния контекста (а иногда - интертекстуального взаимодействия в рамках новозаветной традиции), неточного понимания греческого источника либо искажений в нем. Реже встречаются lapsus calami. В Толст зафиксированы два лексических регионализма МаАъЖена И ко.М(ъ)каннє, - свидетеЛЬствУющие о связях источника с моравской книжной традицией.

Синтаксические дополнения и лексические отступления от оригинала могут приводить к ослаблению связей заглавий с основным текстом послания.

\section{ПРИМЕЧАНИЕ}

${ }^{1}$ Автор выражает благодарность Львовскому историческому музею за предоставление качественной фотокопии рукописи Христинопольского Апостола.

\section{СПИСОК ЛИТЕРАТУРЫ}

Гардзанити М., 2014. Библейские цитаты в церковнославянской книжности. М. : Индрик. 232 с.

Гатри Д., 1996. Введение в Новый Завет. СПб. : Библия для всех. 800 с.

Евфалий, 2013. Евфалий // Православная энциклопедия / под ред. патр. Кирилла. М. : Церковно- 
научный центр «Православная Энциклопедия». URL: http:/www.pravenc.ru/text/187624. html (дата обращения: 08.07.2018).

Зализняк А. А., 2004. Древненовгородский диалект. Изд. 2-е, перераб. М. : Языки славянской культуры. 872 с.

Максимович К. А., 2008. Западнославянское влияние на древнерусский книжно-письменный язык в XI-XIV вв. // Письменность, литература и фольклор славянских народов : XIV Международный съезд славистов (Охрид, 1016 сентября 2008 г.) : докл. рос. делегации ; [редкол.: А. М. Молдован (отв. ред.) и др.]. М. : Индрик. С. 102-125.

Новак М. О., 2014. Апостол в истории русского литературного языка: лингвостилистическое исследование. Казань : Отечество. 316 с.

Новак М. О., 2017а. Греко-славянские синтаксические корреляции в оглавлениях к посланиям апостолов (на материале древнерусских списков XII-XIV вв.) // Древняя Русь. Вопросы медиевистики. № 3 (69). С. 93-94.

Новак М. О., 2017б. Культурно-антропологическое измерение древнеславянских переводов Апостола: лексический уровень // Русский язык и культура в зеркале перевода : VII Международная научная конференция (Афины, 28 апр. 3 мая 2017 г.) : материалы конф. М. : ООО Изд. дом «Неолит». С. 383-391. URL: http://www. esti.msu.ru/netcat_files/userfiles/Files/science/ books/Sbornik\%20Afiny\%202017.pdf

Чевела О. В., 2010. Герменевтика литургической поэзии: Лингвистическое исследование. Казань : Изд-во Казан. ун-та. 346 с.

Blomkvist V., 2012. Euthalian Traditions: Text, Translation and Commentary. Berlin ; Boston : Walter de Gruyter. 403 p.

Tak van der J., 2003. Euthalius the Deacon, Prologues and Abstracts in Greek and Church Slavic Translation. София : Кирило-Методиевски научен центьр (Кирило-Методиевски студии 15). 220 с.

WillardL. S., 2009. ACritical Study of the EuthalianApparatus. Berlin; New York: Walter de Gruyter. 182 p.

\section{ИСТОЧНИКИ И СЛОВАРИ}

ЕвАрx - Архангельское Евангелие 1092 года. Исследования. Древнерусский текст. Словоуказатели. М. : Науч.-издат. центр «Скрипторий», $1997.674 \mathrm{c}$.

ЕвОстр - Остромирово Евангелие 1056-1057 года по изданию А.Х. Востокова. М. : Языки славянских культур, 2007. 968 с.

Толст - Толстовский Апостол, XIV в. РНБ, Q.п.I.5. ТСЛ71 - Апостол № 71, XVI в. РГБ, ф. 304.I.
Христ - Христинопольский Апостол, ХІІ в. Львовский ист. музей, ОР, № 37.

Цитата из Библии - Цитата из Библии. Софт-твари: бесплатный христианский софт // JesusChrist. ru - сервер христианского общения [1999-2013]. URL: http://jesuschrist. ru/ software/bqt5.exe (дата обращения: 08.07.2018).

Чуд - Новый Завет Господа нашего Иисуса Христа. Труд святителя Алексия, митрополита Московскаго и всея Руси / Фототип. изд. Леонтия, митр. Московского. М. : Унив. тип., 1892. 338 с.

Alpha - Alpha. Древнегреческо-русский словарь И.Х. Дворецкого // Version: 3.0. Release: 1 May, 2005. Alpha. Copyright 2005 Sergey Gurin : [программное обеспечение]. URL: http://www. gurin. tomsknet.ru/alpha.html (дата обращения: 07.07.2018).

Migne - Migne J.-P. Patrologiae cursus completus. Series graeca. Vol. 85. Paris : Petit-Montrouge, 1864 p. URL: file://C:/Users/Pro/Downloads/ [Migne,_Jacques_Paul\%3B_saint)._Basile_de S\%C3\%A9leucie](b-ok.org).pdf

Slovník - Slovník jazyka staroslověnského (Lexicon linguae palaeoslovenicae). I-IV. Kurz a kol. Praha : Nakladelství Československé akademie věd, 1966-1997.

\section{REFERENCES}

Garzaniti M., 2014. Bible Quotes in Old Slavonic Literature. Moscow, Indrik Publ., 232 p.

Guthrie D., 1996. An Introduction to the New Testament. Saint Petersburg, Bibliya dlya vsekh Publ. 800 p.

Patriarch Kirill (ed.), 2013. Euthalius. The Orthodox Encyclopaedia. Moscow, Pravoslavnaya Entsiklopediya Publ., 2013. URL: http://www. pravenc.ru/text/187624.html (accessed 8 July 2018).

Zaliznyak A.A., 2004. Old Novgorod Dialect. Moscow, Yazyki slavyanskoy kultury Publ. 872 p.

Maksimovich K.A., 2008. West Slavic Influence on the Old Russian Written Language of the $11^{\text {th }}$ $14^{\text {th }}$ Centuries. Moldovan A.M., ed. Pismennost, literatura $i$ folklor slavyanskikh narodov: XIV Mezhdunarodnyy syezd slavistov (Okhrid, 10-16 sentyabrya 2008 g.): doklady rossiyskoy delegatsii. Moscow, Indrik Publ., pp. 102-125.

Novak M.O., 2014. The Apostolus in the Russian Literary Language History: A Linguistic and Stylistic Study. Kazan, Otechestvo Publ. 316 p.

Novak M.O., 2017a. Greek-Slavonic Syntax Correlations in Chapter-Lists to the Epistles of Apostles (Based on Old Russian Lists of the $12^{\text {th }}-14^{\text {th }}$ Centuries). Drevnyaya Rus. Voprosy 
medievistiki [Old Russia. The Questions of the Middle Ages], no. 3 (69), pp. 93-94.

Novak M.O., 2017b. Cultural and Anthropological Dimension of Old Slavonic Translations of Apostolus: Lexical Stratum. Russkiy yazyk i kultura v zerkale perevoda: VII Mezhdunarodnaya nauchnaya konferentsiya (Afiny, 28 aprelya03 maya 2017 g.): materialy konferentsii. Moscow, Neolit Publ., pp. 383-391. URL: http://www. esti.msu.ru/netcat_files/userfiles/Files/science/ books/Sbornik $\% 20$ Afiny $\%$ 202017.pdf.

Chevela O.V., 2010. Hermeneutics of Liturgical Poetry: A Linguistic Study. Kazan, Izd-vo Kazan. un-ta, $346 \mathrm{p}$.

Blomkvist V., 2012. Euthalian Traditions: Text, Translation and Commentary. Berlin; Boston, Walter de Gruyter. 403 p.

Tak van der J., 2003. Euthalius the Deacon, Prologues and Abstracts in Greek and Church Slavic Translation. Sofiya, Kirilo-Metodievski nauchen centar. $220 \mathrm{p}$.

Willard L.S., 2009. A Critical Study of the Euthalian Apparatus. Berlin; New York, Walter de Gruyter. $182 \mathrm{p}$.

\section{SOURCES AND DICTIONARIES}

Arkhangelsk Gospel of 1092. Research. Old Russian Text. Word Markers. Moscow, Skriptoriy Publ., 1997. 674 p.
Ostromir Gospel of 1056-1057 after the Edition of A.Kh. Vostokov. Moscow, Yazyki slavyanskikh kultur Publ., 2007. 968 p.

Tolstovsky Apostolus, 14th cent. National Library of Russia, Q.n.I.5.

Apostolus No. 71, 16th cent. Russian State Library, F. 304.I.

Christinopolskiy Apostolus, 12th cent. Lviv Historical Museum, No. 37.

Bible Quote. Soft Creatures: Free Christian Software. JesusChrist.ru - Christian Communication Server (1999-2013). URL: http://jesuschrist.ru/ software/bqt5.exe (accessed 8 July 2018).

The New Testament of our Lord Jesus Christ. The Work of St. Aleksii, Metropolitan of Moscow and all Russia. Moscow, University Press., $1982.338 \mathrm{p}$.

Alpha. Ancient Greek-Russian Dictionary by I.Kh. Dvoretsky. Version: 3.0. Release: 1 May, 2005. Alpha. Copyright 2005 Sergey Gurin. URL: http://www.gurin.tomsknet.ru/alpha.html. (accessed 8 July 2018).

Migne J.-P. Patrologiae cursus completus. Series graeca. Vol. 85. Paris, Petit-Montrouge. 1864 p. URL: file://C:/Users/Pro/Downloads/[Migne, Jacques_Paul\%3B_saint)._Basile_de_S\%C3\% A9leucie](b-ok.org).pdf.

Slovník jazyka staroslověnského (Lexicon linguae palaeoslovenicae). I-IV. Kurz a kol. Praha, Nakladelství Československé akademie věd, 1966-1997.

\section{Information about the Author}

Mariya O. Novak, Doctor of Sciences (Philology), Associate Professor, Department of Russian Language and Applied Linguistics, Kazan Federal University, Kremlevskaya St., 18, 420008 Kazan, Russia,mariaonovak@gmail.com, https://orcid.org/0000-0002-5501-8510

\section{Информация об авторе}

Мария Олеговна Новак, доктор филологических наук, доцент, доцент кафедры русского языка и прикладной лингвистики, Казанский федеральный университет, ул. Кремлевская, 18, 420008 г. Казань, Россия, mariaonovak@gmail.com, https://orcid.org/0000-0002-5501-8510 